\title{
Looking for clues
}

\section{Murderous Methods: Using Forensic Science to Solve Lethal Crimes by Mark Benecke \\ Columbia University Press: 2005. 304 pp. $\$ 24.95$}

\section{Anthony Busuttil}

Judging by what we see in the media, the public seems to have an insatiable appetite for reading about murder. This is especially true for serial murders or ones that are particularly heinous and perverse, or where attempts were made to conceal the crime. People like to exercise their little grey cells' and try to solve the crimes themselves.

In Murderous Methods, Mark Benecke refers to a multitude of homicide cases, some more recent than others. He explains how the evidence was collected and critically discusses how the case came to be solved.

Benecke's pedigree is impeccable: he has a vast knowledge of forensic science, involving such activities as facial reconstruction, forensic anthropology, thanatology (the description and study of death and dying) and fingerprint comparison. He has been involved personally in, or has carefully studied, some causes célèbres, both in his native Germany and worldwide, including the Lindbergh kidnapping and the O. J. Simpson case.

This strange mélange of cases is an unorthodox contribution to the literature on forensic science. I suspect that the book is really aimed towards the interested and experienced lay reader, rather than a scientific audience, given the author's close association with the media and his failure to delve to any significant depth into the scientific background of the investigation.

The book is anecdotal rather than didactic. It does not address any particular theme, and the five chapters do not appear to be obviously interlinked. The cases it discusses are all genuine, with no romanticized, intricate or intriguing plots of the sort you would find in a best-selling thriller, but they serve to demonstrate the deviousness and perverse cruelty of human nature. The author also regularly diverts the reader's attention to para-forensic subjects, such as the embalming of Lenin's body, the possibility of life after decapitation, the rate and manner of decomposition of a human cadaver, and so on.

Benecke dispels the myth that all you need to solve crimes is sophisticated DNA profiling, some expensive imaging and magnification equipment, and a team of scientists slaving away in a laboratory. In truth, it often requires meticulous and painstaking police sleuthing, the laborious collection of evidence, careful interviews of witnesses, the application of common sense and principles of logic, and close adherence to the tenet that nothing is quite

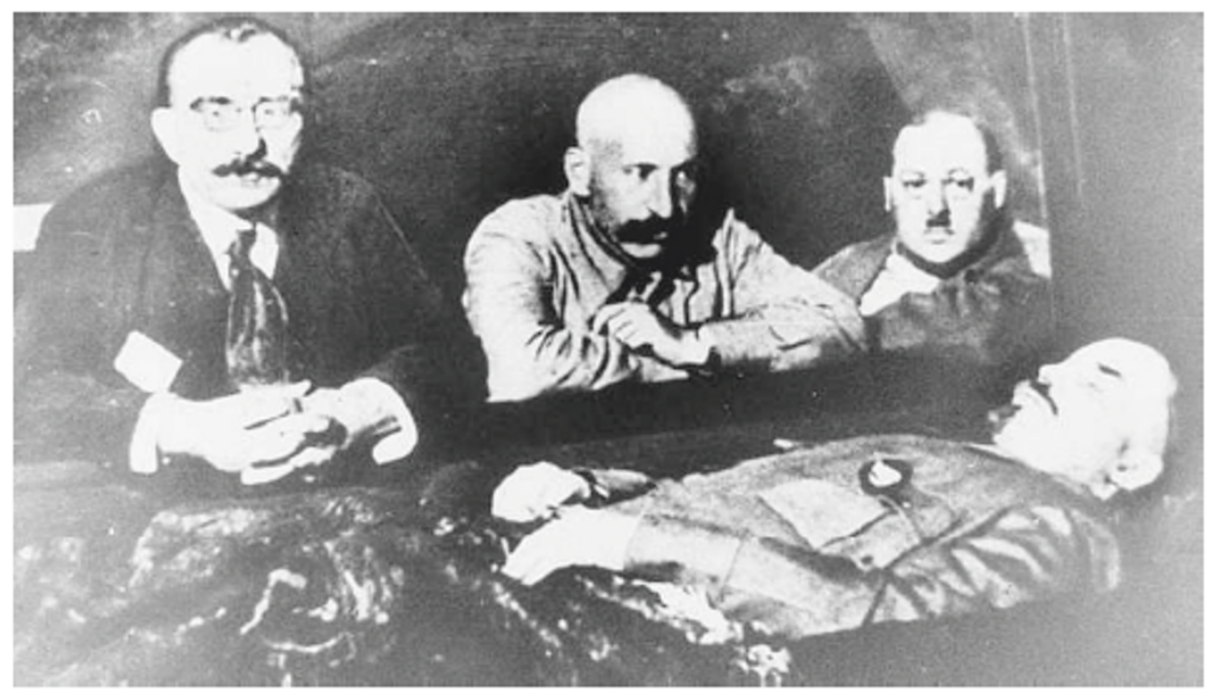

Stopping the rot: a combination of chemicals and frost helped to preserve Lenin's corpse.

what it seems. Only when the evidence has been carefully collected, sifted and collated can the case can be presented for judicial scrutiny.

The book explores the judicial systems of mainland Europe, with special emphasis on Germany, which is perhaps the cradle of science-based investigation of crime. Germany has an inquisitorial legal system, in which the judges seek to determine the facts of the case. This is different to the adversarial system used in Britain, and other countries linked to Britain, in which the judge acts as an impartial referee between two opposing parties, with one side attempting to demolish the case presented to the court by the other side. This aspect is

\section{Turning to fraud}

\section{Intuition}

by Allegra Goodman

Dial Press: 2006.352 pp. $\$ 25$

\section{Jennifer Rohn}

The writer Allegra Goodman is not a scientist, but she certainly could have fooled me. Her latest novel, Intuition, brings back the sights, sounds and smells of a dozen years at the lab bench, stimulating emotions I had forgotten I'd experienced. In lieu of direct research experience, Goodman consulted several scientists in her family and also shadowed some researchers at the Whitehead Institute in Cambridge to produce an exacting portrait of the rise and fall of a cancer-biology lab.

When flailing postdoc Cliff stumbles on a potentially big result, joint lab head Sandy Glass appropriates it as fodder for a sorely needed new grant. This goes against the better wishes of his scientific partner Marion Mendelssohn, not discussed as openly in other similar books.

Murderous Methods was originally published in German in 2004, and in this English version the narrative is wooden and in places slightly incomprehensible. The few illustrations, although authentic, are poorly reproduced and add little value. Most of the references at the end are not to scientific journals or books, but to general literature, although they are reasonably extensive. Overall, however, the book is a good read, being interesting, varied and eloquent - but it is not for the faint-hearted. Anthony Busuttil is regius professor of forensic medicine at the Medical School, University of Edinburgh, Teviot Place, Edinburgh EH8 9AG, UK. whose more scrupulous approach is respected but has done the lab few favours. The premature result is coaxed into a Nature paper, and fame and funding soon follow. But when fellow postdoc Robin, who also happens to be Cliff's lover, suspects that the finding has been faked and accuses him, the close-knit lab begins to unravel.

The story is set in the 1980 s, the same decade as the 'Baltimore affair', in which a researcher, Margot O'Toole, accused her boss, Thereza Imanishi-Kari, of fraud and set off a national furore. Yet the story still resonates today: the recent South Korean stem-cell scandal also involved too-good-to-be-true results, lab whistleblowers and the downfall of a mediagenic scientist, Woo Suk Hwang. But Intuition diverts our attention from the bare facts to psychological motives: what might make a successful researcher extend that little bit further into the realm of fudging? You 